\title{
New Progress of Rheology in Industrial Field, Contribution to Development and Enlightenment in Psychorheology
}

\author{
Yoshiyuki NABATA ${ }^{\dagger}$
}

\begin{abstract}
We have tried to measure purely mechanical sensory feelings of cosmetics with using commercial rheometers. To obtain mechanical parameters relating to the score of sensory feeling, we have to measure under the same condition during the evaluation of sensory feeling, that is, the movement of finger and the structure of cosmetics. Sensory feelings of madeup skin can also be measured using stress-controled rotaional rheometers if we fix a measuring part of human body without stress.

Understanding the rheological properties of cosmetic emulsions is helpful to design a new product with a desired sensory feeling. Emulsions with high dispersoid concentration have yield point, but high concentration linear polymer solution dose not. This was qualitatively explained with the difference in mobility at the contact point between dispersoids.

Key Words: Rheology / Psychorheology / Sensory feeling / Cosmetics / Emulsion
\end{abstract}

\section{レオロジーの産業分野への新展開, 特にサイコレオロジー分野の開拓と啓蒙に関する功績}

\section{名畑 嘉之}

（原稿受理：2021 年 9 月 12 日）

\section{1. はじめに}

35 年間の花王株式会社在職中, 前半途中の 5 年間程度を 除き, レオロジー手法を使って研究業務を行った。 レオロ ジーとの付き合いは入社配属の 1 週間後から突然に始まった. 「新規購入するレオメータを使って仕事を。ただし, 遊ぶ な.」が新人の私に課せられた漠然としたテーマであった。 「仕事を」は研究開発への貢献と理解できたが, 「遊ぶな」に ついては意味がわからないままに仕事を始めた。今振り返る と,「遊ぶな」については“学問のための研究ではなくて, 商品開発に役立つ研究を”という意味であったようだ。レオ ロジーについては素人で, レオロジーに関する市販書籍や文 献を読みながらの取り組みであった，救いであったのは，学 生時代に誘電緩和を使って固体高分子の分子運動を計測して いたこともあり, 動的粘弾性デー夕を活用することについて の障壁は低かった。

入社直後から前半の仕事は, 乾式複写機におけるトナーの 定着機構の理解, 硬質ウレタンの硬化過程計測法の構築, 磁 気記録テープ用支持体フィルムが満たすべき物性の把握と改 良など，高分子レオロジーの範疇で扱えるものであった。 た た，驚いたのは「レオメータで仕事を」という話であったに もかかわらず，レオロジーの言葉が全く通じずとまどった。 得られた結果の説明に際し，相手が理解できるように説明す

† E-mail : ynabata@feel.ocn.ne.jp
ることが常に求められたが，この状況はずっと続いた.

在籍後半は情報事業からの撤退による社内失業状態から始 まった。いくつかのテーマを試行錯誤した結果, レオメータ は自由に使える環境があったことより，レオロジー手法を 使って商品開発支援を行うことにした。所属グループ内の化 粧品関連支援の仕事をしていたメンバーからの誘いがあり, 化粧品開発の支援から始めた。化粧品開発メンバーとの仕事 上のつき合いが始まり, 自社および他社商品の性能評価, 処 方や製造条件違いが製品性能に及ぼす影響の把握，等のテー マがありそうと感じていた。 そんな中で, 固形ファンデー ションや棒状口紅の開発メンバーから,「化粧品の使用感触 は官能評価であるため, 評価者の育成に時間がかかることと, 体調の影響も受け易い. 使用感触を物性で定量的に評価でき ないか?」という相談があった，使用感触は化粧品の受け入 れ性や継続使用性を左右する重要な商品性能であることより, レオロジーによる化粧品感触評価の可能性から検討すること にした、今思えば, サイコレオロジーとの取り組みはここか ら始まった。最もレオメータ計測に向かない剂型の化粧品か ら開始したが，これら剤型で結果を出せたことにより ${ }^{1,2)}$, 他のレオロジーで計測し易い剤型での検討は比較的楽であっ だ． 性状が似たワックスサンプルでのレオロジー計測の経 験があったことより，棒状口紅から検討を開始した。棒状口 紅と固形ファンデーションの感触をどのように測定するかを 試行する中で, レオメータを使って感触計測を行うために必 要な考え方を獲得することができた。 
後述するように, 力学的な感触のレオメータを用いた計測 は, 感触認知時の状況を再現した計測を工夫すれば目的とす る結果が得られる。化粧品開発のためには, 保存安定性等の 他の性能も満たしつつ, どのようにしたら欲しい感触を実現 できるかも求められる。 そのためには感触を発現している力 学特性が何で, どのような製剤構造にすればそうなるのかの 知見の蓄積も必要となる。 2008 年の 12 月に「サイコレオロ ジー研究会を始めないか」というお誘いをいただいた。“感 性視点での商品設計”という話題が取り上げられ始めた頃で あったが，お声がかかったのは，2003 年の討論会で“口紅 の使用感とレオロジー” と題した発表を行ったことに端を発 していると思っている. この発表を行ったのは, 口紅の感触 をある方法 (シャーレ法 ${ }^{1)}$ ) で練った状態の口紅サンプルの レオロジー特性から評価できたが, 本法の妥当性を世の中に 問うてみたかった為である。私としては，レオロジーによる 化粧品開発支援という仕事の一つがサイコレオロジーであっ たが, それ以上に化粧品レオロジーの理解が重要であると考 えていた。 そのため,「サイコレオロジー（含む，化粧品の レオロジー）であれがお引きうけします」とお答えしたとこ ろ，自由にやったら良いという返事をいただいた。また、レ オロジーを使った商品開発支援を続ける中で, 物理や数学が 苦手な方々にとっては, レオロジーへの入門は難しいと感じ ていた，研究会では興味を抱いていただけるようなサイコレ オロジーのテーマの講演に加え, レオロジーの易しい入門講 座も盛り込んだ. 以下, レオロジーによる化粧品開発支援と して, レオメータを使い感触計測を試みた例を簡単に, 化粧 品レオロジーのための基礎データの獲得を試みた例について, 定性的な議論ではあるが,この場を借り紹介させていただく.

\section{2. レオロジーによる化粧品開発支援}

\section{1 化粧品感触のレオロジ一計測（サイコレオロジー）}

先に記したように, 化粧品感触のレオロジー計測の最初は, 固形ファンデーション（以下, FD）と棒状口紅（以下, 口 紅）で，ほほ同時期に相談があった。粉体成形体である FD については, 成形固体であるため, 力を加えるとボロボロと 崩れる. 第一印象で, FDのレオロジー計測は直ぐには無理 と判断した， 口紅については，固体だが，脆く，指で触ると 融ける物であった。ワックスや低分子量ポリマーのような物 と見なせば, レオメータセル中で溶融固化させればレオロ ジー計測は可能と考え, 口紅の感触計測から試みた。しかし ながら, この方法では感触を計測するには不十分な結果しか 得られなかった。これは, 感触評価時の口紅の状態を計測し ていないため, 今思えば, 当然の結果であった。

化粧品感触のレオメータ計測に取り組んだ際, 最初に考え たことは, “本当に化粧品の感触をレオロジー計測できる か? ”である. 自分自身が化粧品を肌に塗布して感触認知を どのように行っているかを考えてみた. 化粧品容器から化粧 品塊を指先に取り, 肌上に塗り広げてみた。指を動かし塗り 広げるに従い化粧品塊は変形し, 変形に応じて応力を発生す る. 指先の動きから化粧品塊の変形や変形速度を, 指先や肌 が化粧品塊から受ける力を触覚等で感じ, 変形または変形速 度と発生する力との関係を知り, それを“塗布感が軽いとか 重い”といった感触ワードとして表現しているようである. この感触の認知動作は，見方を変えれば，指先を使ったレオ
ロジー測定やトライボロジー測定そのものと見なせる。つま り, 純粋に力学起源の感触であればレオロジー測定やトライ ボロジー測定により, 相関性を示す力学パラメータが得られ ると期待できる。ここで, トライボロジー測定となるのは, 指先表面と化粧肌表面間の滑りが支配的になる場合である. 法線方向の力と位置制御もできる回転型レオメータを使えば, 力学起源の感触をレオロジー測定やトライボロジー測定によ り計測できるはずである。

化粧品の力学起源の感触を計測するためには，1）感触 ワードの内容を知る，2）感触認知時の化粧品の状態を知る ことが必要である，1）については，その意味するところが, 直感的にわからない感触ワードもある. どのような動作のと きに認知される感触かを聞き取り, 測定方法を決定する必要 がある，2）については，感触認知時に化粧品がどのような 状態にあるかを観察・推測し，それを測定セル中で再現しな くてはならない，化粧品の塗布動作に伴い，口紅では固体状 態が崩れスラリー状態へと ${ }^{1)}$, FD では粉体成型物が崩れて 塗膜状態へと変化する ${ }^{2)}$. 乳化物などでは, 塗布に伴い揮発 成分の揮発に伴う組成変化により乳化状態が壊れたりする 対象とする感触がどの状態で認知される感触かということを 考えて計測を行わないと目的とする結果は得られない.

感触ワードの中にはどのような感触であるかをイメージし 難いものがあるが, レオメータ計測によりその内容がわかる 場合がある。その一つに, 塗布初期に感じる “こく感”があ る31. ヒントになったのは“さらっと感”で, こちらは塗布 時に指先等が感じる抵抗感が小さいというイメージである. 官能評価の“こく感がある”スコアと“さらっと感がある” スコア間には強い負の相関性があったことより, “こく感” についても塗布時の抵抗感が関係した感触であると予想した. 塗布初期の指先等が受ける抵抗感を知るには, サンプルの静 置時の構造が壊れて流動を始める部分を計測できる動的粘弾 性のひずみ依存性測定が向く。クリームについて得られた結 果を Fig. 1 に示す. Fig. 1 上図は動的粘弾性のひずみ依存性 より求めた見かけ貯蔵弾性率 $G_{\text {app }}^{\prime}$ を応力を横軸にしてプ ロットしたもので, 応力印加（塗布の進行）に伴い指先等が 感じる抵抗感 $\left(G_{\text {app }}^{\prime}\right.$ 值 $)$ がどのように変化するかを示して いる。ここで貯蔵弾性率をみかけと記したのは, 非線形ひず み域までの結果をプロットしているためである。この図より， 線形ひずみ域と $G_{\text {app }}^{\prime}$ が急激に低下した直後の部分の $G_{\text {app }}^{\prime}$ 曲 線を直線でそれぞれ近似し, それらの交点の応力值を求め, $G_{\text {app }}^{\prime}$ が急激に低下するときの応力值 $\sigma_{\mathrm{d}}$ とした. Fig. 1 下図は, この応力值 $\sigma_{\mathrm{d}}$ と “こく感 (richness)” スコアとの関係を示す. “こく感” スコアは 60 名の一般消費者の方々の官能評価結果 である。 6 品の市販クリーム商品をお使いいただき,「この クリームは“こくがありますか”」という質問をし，「そう思 う」,「ややそう思う」,「どちらともいえない」,「あまりそう 思わない」，「そう思わない」の 5 段階での回答をお願いした。 「そう思う」と「ややそう思う」の回答数の和が全回答中に 占める割合を百分率で示し，この值を “こく感” スコアとし た，図からわかるように， $\sigma_{\mathrm{d}}$ 值が高い方が “こく感”が強 かった。 なお, クリーム L がこの相関性から外れたのは, このクリームのみが線形ひずみ域の挙動が液体的であった為 と考えた。 “こく感”とは塗布動作時に指先等が受ける抵抗 感が急激に低下するときの応力值と関係する感触であること がわかった。 
化粧品製剂のレオロジー特性より感触スコアと相関性を示 すレオロジーパラメータが得られるケースが多いが, 乳液の “べたつきのなさ”については製剤の測定のみでは無理で あった ${ }^{3)}$. 乳液の研究開発技術者 $10 \sim 13$ 名が市販乳液 14 品 の “べたつきのなさ”を，標準品を 0 としてー4〜+4の9段 階で評価（プラス值が大きいほど感触良好）した系について 検討した結果を紹介する。塗布時および塗布後の“べたつき のなさ”スコア間に正の強い相関があったことより, 乳液の 構造は塗布中から変化しているのではと考えた。塗布に伴い 製剤の空気や肌との接触面積が増えることと, 肌温度が $30{ }^{\circ} \mathrm{C}$ を超えていることより, 水等の揮発成分の濃度低下が 大きく，製剤の乳化構造は変化し易いと考えた，そこで，製 剤をシャーレに入れて室温大気下で乾燥させたところ, 乾燥 により結晶が析出するもの, ペースト状になるもの, 餅状に なるものがあった。乾燥物の性状と感触やレオロジー特性と の関係を調べたところ, “べたつきのなさ”に優れるものは 乾燥により結晶が析出するもので, その中では角周波数 $1 \mathrm{~s}^{-1}$ での $\tan \delta$ 值が低い方が“べたつきのなさ”に優れた.

Fig. 2 に塗布後の “べたつきのなさ”の例を示すが, 乾燥物 がグリース状や餅状になるものについては, ズリ速度 $1000 \mathrm{~s}^{-1}$ での第 1 法線応力差 $N 1$ が小さい方が “べたつきの なさ”に優れた

塗布時の感触については, 化粧品製剤やその乾燥物のレオ ロジー特性より感触と相関性を示す力学パラメー夕を見出す ことができる。しかし化粧肌の感触については, 化粧を施す ことにより肌の状態が変化することもあり, 化粧肌そのもの の力学特性を計測しなければならない. 市販のレオメータは ヒト肌を計測するのに必要な基本性能は有するため, 何とか 肌の計測を行えないかを考え続けた. ヒト肌のレオロジー計
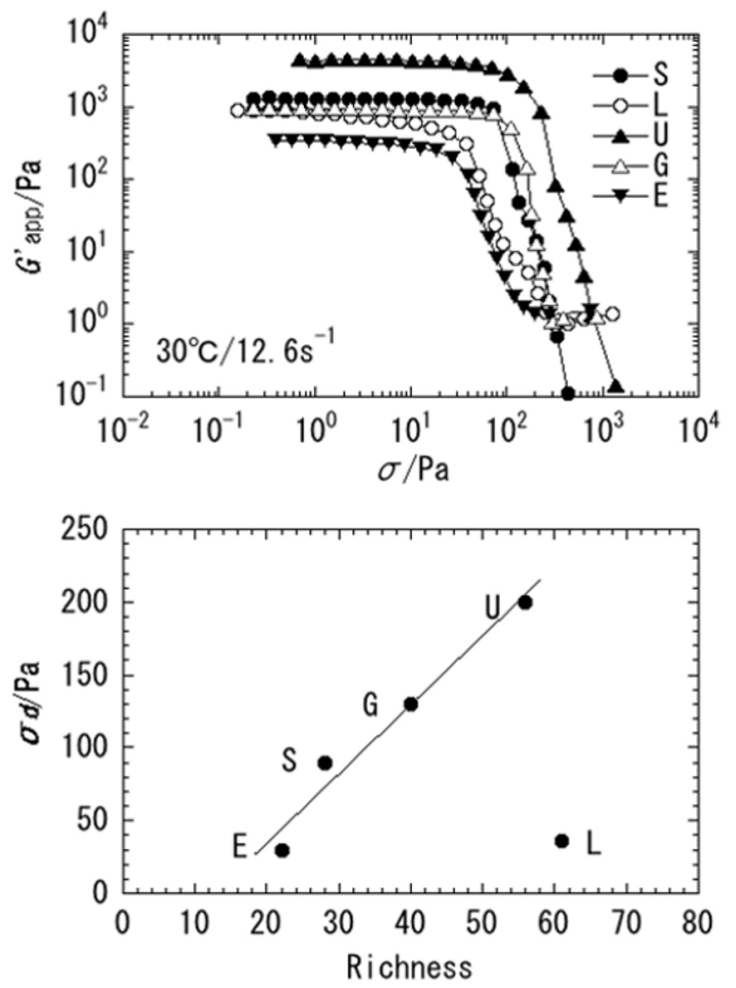

Fig. 1 Upper panel: Apparent storage modulus $G_{\text {app }}^{\prime}$ vs. stress plots for cream samples. Lower panel: Stress $\sigma \mathrm{d}$ at abrupt decrease of $G_{\text {app }}^{\prime}$ vs. richness ("koku" in Japanese) score plots for cream samples.
測を実現するには，1）レオメータの測定セル部より大きな サンプルを計測できる，2）肌の深さ方向の位置と押し付け 力を制御できる，3）測定時にヒトにおよぼす負荷が少ない, という条件を満たす必要がある。法線方向の位置と力の制御 もできる応力制御式の回転型レオメータを使い, モーターに 繋がったシャフトに測定セルを付けて測定部位に当てる形に すれば，1）と2）の条件は満たすことが可能である．3）に ついては，測定部位を上腕内側とし，腕を負荷の少ない状態 で固定し，測定時間を 30 秒前後までに抑えれば満たすこと が可能ではという考えに至り，実際に計測を試みた4)

Fig. 3 に前腕内側部に 3 種の市販化粧水を塗布した前後の 塗布部位の硬さの変化を測定した結果を示す。測定は動的粘 弾性測定モードで行い，測定周波数 $2 \mathrm{~Hz}$ ，振動角度は 0.8 度 （線形ひずみ内）とした。プローブは滑り止め加工を施した 直径 $8 \mathrm{~mm}$ のアルミニウム製円板で，測定部位への押し付け 力は $1 \mathrm{~N}$ とした。各測定に際しては, 最初に押し付け力 $1 \mathrm{~N}$ への制御 (5 秒間)，続いて，押し付け力を $1 \mathrm{~N}$ に制御した 状態で，計 10 点（測定間隔は 3 秒）の動的粘弾性測定を実 施した。測定部位の硬さの指標としてはトルク值を選び，各 測定時における後半の 5 点の平均值を計測值とした。測定は 化粧水塗布前および塗布後の各経過時間で行った。なお，各 測定間では，測定プローブは測定部位から離し，化粧水の乾 燥を妨げないようにした。化粧水塗布前および塗布後の各経 過時間での検出トルク值について，両トルク間の差分を塗布 前のトルク值で割り，トルク変化率とした。

図からわかるように，どの化粧水も塗布により肌が柔らか くなるが, その後の挙動は化粧水ごとで異なった。化粧水 $\mathrm{A}$ では，直後から，時間の経過とともに肌が硬くなっていった．

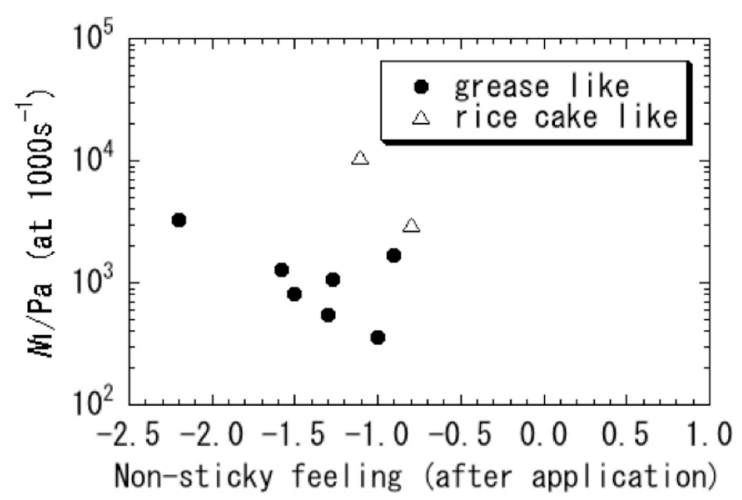

Fig. 2 First normal stress difference $N 1$ vs. non-sticky feeling score plots.

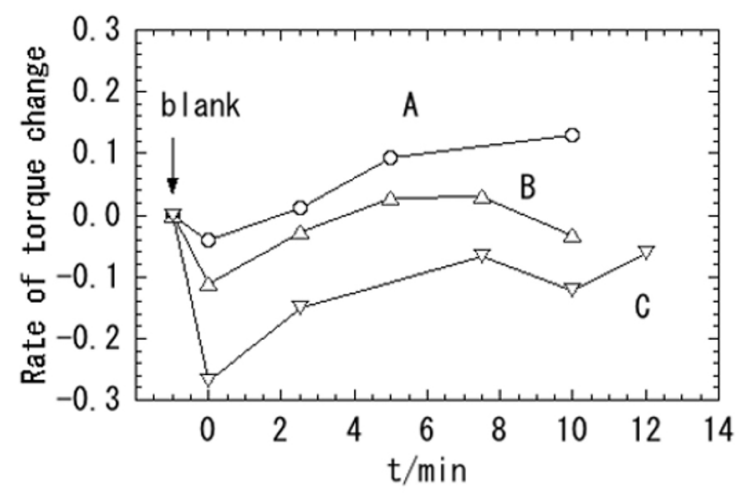

Fig. 3 Rate of torque change vs. time plots after application of lotion. 
化粧水 B では数分後には塗布前の硬さに戻った. 一方, 化 粧水 Cでは塗布後 10 分程度は柔らかい状態が続いた。これ らの挙動は官能評価と一致したが, このような差が生じる原 因については不明で, 今後の課題である。

\section{2 化粧品レオロジーの把握へ向け}

化粧品には溶液 (化粧水, 等), 乳化物 (乳液, クリーム, 等), 乳化分散物 (リキッドファンデーション, 等), 溶融固 化物 (口紅, 等), および粉体成型物（固形ファンデーショ ン）などさまざまな剤型がある。乳化物は液滴が分散した物 なので，化粧品の剤型としては分散物が圧倒的に多いことに なる. 分散物のレオロジー特性の理解は高分子溶液のように は進んで扔らず，化粧品のレオロジーを知るには，先ずは， 分散物のレオロジー特性を知る必要がある。分散物では液滴 や固体粒子が連続相中に分散しているが，高分子溶液を高分 子糸まり（一本の高分子鎖が球状に広がって溶媒に溶けてい る状態）が分散しているものと考えれば, 高分子溶液も分散 物と見なせる. 分散質の性質の違いがレオロジー特性に反映 されるはずなので, 高分子溶液のレオロジー5) と比較するこ とで分散物のレオロジーを理解し易いと考えた。

濃度の異なる高分子溶液（ポリアクリル酸ナトリウム, 分 子量：141万-188 万）と水中油型（O/W）乳化物（油剂は スクワラン, 活性剤濃度は $2.5 \%$ ）について，十分静置した 状態での複素弾性率 $G^{*}$ の角周波数 $\omega$ 依存性を Fig. 4-1 に,

粘性率 $\eta$ のずり速度依存性（最初にずり速度を上げながら測 定した up 過程, 続いて速度を下げながら測定した down 過 程の結果）を Fig. 4-2 にそれぞれ示す. 図中の数字は分散質 の濃度（mass\%）である. Fig. 4-1の $G^{*}$ の角周波数依存性に おいて, 低濃度サンプルの挙動は似ている. 両サンプルとも
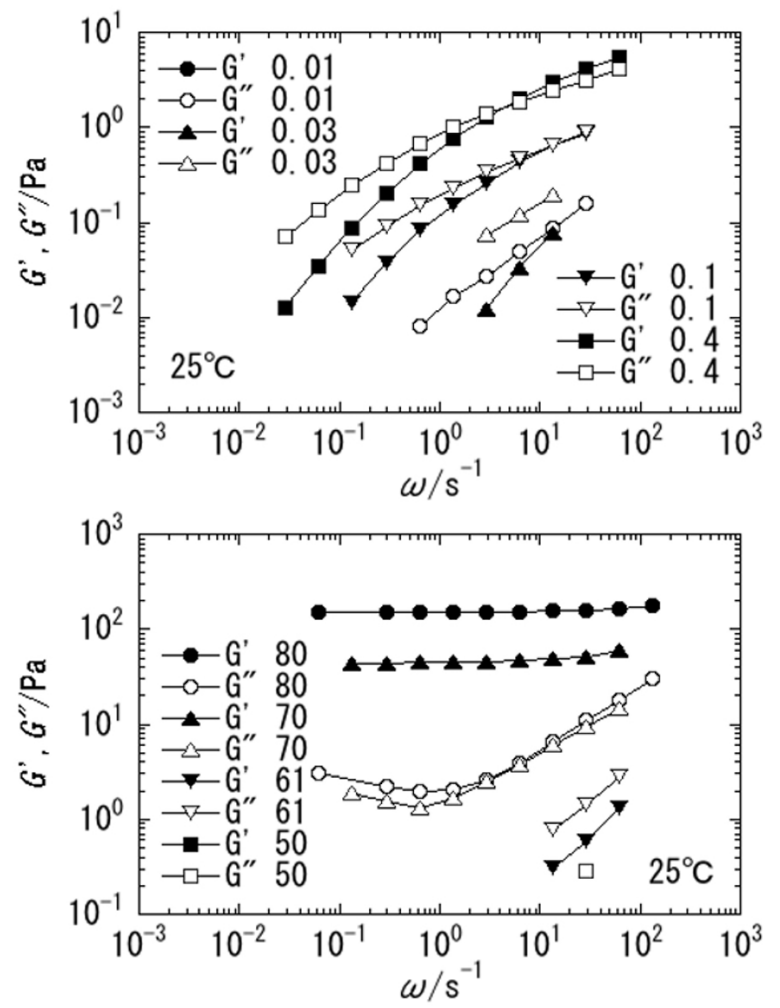

Fig. 4-1 Storage modulus $G^{\prime}$ and loss modulus $G^{\prime \prime}$ vs. angular frequency plots for polymer solution samples (upper panel) and emulsion samples (lower panel).
に最も濃度が低いサンプルでは粘性項（損失弾性率 $G^{\prime \prime} ）$ の みが観測され，濃度の増加に伴い弾性項（貯蔵弾性率 $G^{\prime}$ ) も観測されるようになる。 $G^{\prime}$ と $G^{\prime \prime}$ 值ともに, 角周波数の低 下に伴い直線的に減少し $\left(G^{\prime}<G^{\prime \prime}\right)$, この濃度域ではサンプ ルは流動できることを示す。高濃度域になると挙動は異なり， 高分子溶液では $G^{\prime}$ と $G^{\prime \prime}$ 值ともに低角周波数域へ向けて小 さくなるが, ある角周波数值を境に, 高角周波数域では $G^{\prime}>G^{\prime \prime}$ で, 低角周波数域では $G^{\prime}<G^{\prime \prime}$ となる。一方, 液滴 分散物では $G^{\prime}$ 值の角周波数依存性は小さくなり, 全角周波 数域で $G^{\prime}>G^{\prime \prime}$ となる。

$\eta$ のずり速度依存性（Fig. 4-2）において, 両サンプルとも に up 過程と down 過程の $\eta$ 值の一致は良く, ずり速度の履 歴に依存していない。これは定常流動状態では一定の $\eta$ 值で あることを示している，分散質の濃度依存性については，当 然ではあるが， $G^{*}$ の角周波数依存性と同様な傾向が見える. 低濃度域では，表面張力の影響で上手く計測できていないが, 両サンプルともに一定の $\eta$ 值をとる。濃度が少し上がってく ると, 低ずり速度域では一定の $\eta$ 值を（表面張力の影響で上 手く計測し難いが), 高ずり速度域では速度の増加とともに $\eta$ 值が低下するずり軟化現象を示す，高濃度域では，高分子 溶液については低ずり速度域では一定の $\eta$ 值を, 高ずり速度 域ではずり軟化現象を示すが，ずり軟化現象を示し始めるず り速度は低下し, ずり軟化の程度も大きくなる。一方, 液滴 分散物では，全ずり速度域でずり軟化現象が観測される。

Fig. 4 の高分子溶液と乳化物の挙動の違いは, 次のように 考えれば定性的に説明できると考える。分散質濃度の増加に 伴い，分散質同士は接触しだし凝集体が形成され，ある程度 以上の濃度では凝集体が系全体に広がった網目構造が形成さ れ，さらに濃度が上がれば分散質が系全体を占めるようにな
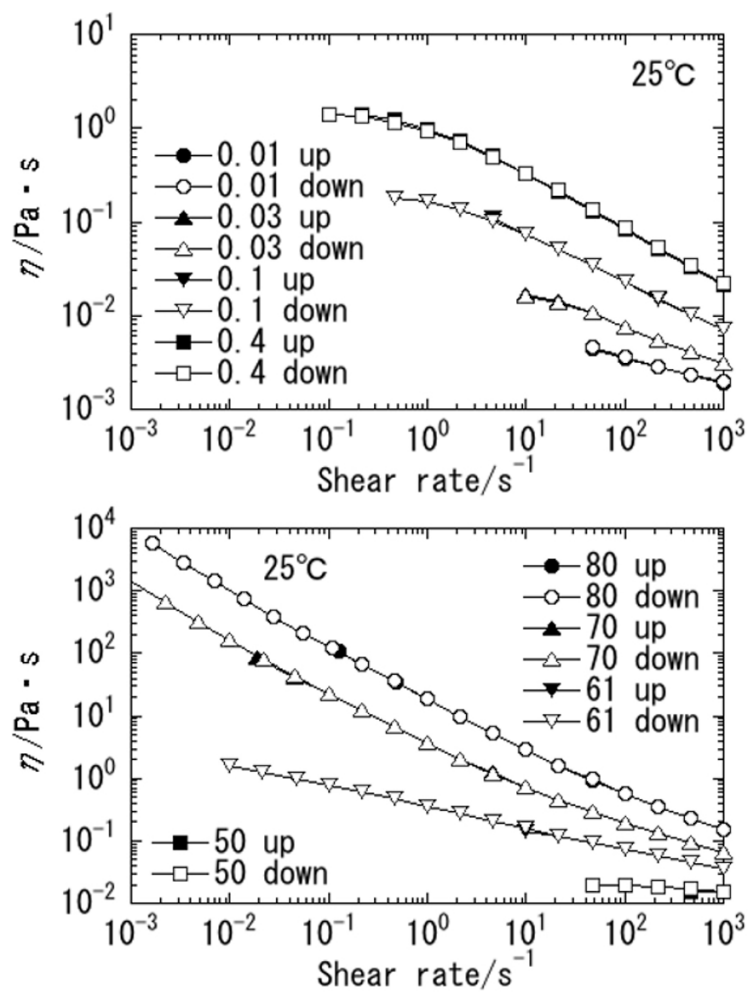

Fig. 4-2 Viscosity $\eta$ vs. shear rate plots for polymer solution samples (upper panel) and emulsion samples (lower panel). 
る。レオロジー特性に影響するのは，分散質それ自体と分散 質接触部の運動性であろう。高分子の場合には高分子鎖の熱 運動により分散質の変形が可能であるのに対し, 十分な機械 力をかけて調製された液滴形状が球形の乳化物では通常のレ オロジー測定のひずみやひずみ速度下では分散質は変形しな いようである（報告されているようなずり速度に比例した法 線応力の増加 ${ }^{6}$ を観測したことがない). 分散質の接触部の 運動性については, 高分子の場合には接触部は高分子鎖の幾 何学的な絡み合いにより形成されている. そのため, 高分子 鎖の鎖方向のレプテーション運動により絡み合い点（接触 部）の解消（マクロな流動）が可能である. 分散質が液滴の 場合は, 液滴表面部での接触であり, 運動性としては接触面 内方向での滑りは許されると考えられる。

分散質が離散的に分布する低濃度域では，連続相の流動性 が支配するために $G^{*}$ の角周波数依存性では角周波数の低下 に伴い直線的に減少する $G^{\prime \prime}$ 項のみが, $\eta$ のずり速度依存性 では一定の $\eta$ 值が観測される。分散質濃度が上がってくると, 高分子では分散質の変形や配向に伴う粘弾性応答が観測され るようになるが, 分散媒が流動性を支配するので, $G^{\prime}$ と $G^{\prime \prime}$ ともに角周波数の低下に伴い直線的に低下寸る $\left(G^{\prime}<G^{\prime \prime}\right)$. 液滴分散物では凝集体が形成され始め, 接触部での滑りに起 因する粘弾性応答が観測されるようになるが，分散媒が流動 を支配するので $G^{\prime}$ と $G^{\prime \prime}$ ともに角周波数の低下に伴い直線 的に低下する $\left(G^{\prime}<G^{\prime \prime}\right)$. さらに濃度が上がり, 凝集体が系 全体に広がってくると, サンプルの流動性は広がった凝集体 に支配されるようになる。高分子溶液の場合には凝集体の接 触部は高分子鎖の絡み合いでできているので, 分子鎖方向に 沿った鎖のレプテーション運動により絡み合いが解消でき (マクロに流動でき), この時間スケール（緩和時間 $\tau$, $\tau=1 / \omega)$ が流動性を支配することになる. Fig. 4-1 で $G^{\prime}$ 曲線 と $G^{\prime \prime}$ 曲線が交差する点がこの緩和時間と関係しており, こ れより高い角周波数域では絡み合い点が架橋点として働くの で $G^{\prime}>G^{\prime \prime}$ となり, 低い角周波数域では架橋点が解消される ので $G^{\prime}<G^{\prime \prime}$ となりマクロな流動が生じる. 分散質が液滴の 場合, 凝集体のサイズが小さく, 動ける空間がある間はこの 滑りは生じ易いが, 凝集体が系全体に広がるようになると動 ける空間がなくなり, 周りの凝集体との協同的な動きが必要 になり, 滑り運動の速度の低下と滑り距離の減少が生じてく る. 液滴の充填が十分進んだ状態になると, 滑りの速度はさ らに遅くなり, Fig. 4-1のように低角周波数側へ向かっての 粘性項の増加傾向が観測されるようになる. Fig. 5 に, Fig. 4-2 の up 過程測定時の応力 - ひずみの関係を示す. 液滴 が十分に充填された状態のサンプルでは, 線形ひずみ域の応 力ーひずみの関係が傾き 1 の直線となり, これらサンプルが 固体状態であることがわかる。液滴が十分に充填された乳化 物はマクロには流動できず，流動させるには共同運動を生じ させるに必要な応力 (降伏応力) 以上の応力を印加する必要 がある. 先に記した “こく感” 感触を出すには, サンプルに 降伏応力を持たすのが有効で, 乳化物の内相の充填率を高め る処方設計が求められることになる.

乳化物のレオロジー特性を把握する際に, 一点, 注意が必 要である。界面活性剤を用いて乳化物を調製するが，使用す る界面活性剂が多いと, 液滴を安定化させている界面活性剂 の液滴／連続相界面に形成される配列構造に加えて, 余剩界 面活性剂から成る会合体が連続相中に形成される。液滴が分
散している構造と考えている乳化物のレオロジー特性に余利 界面活性剤が形成した会合体のレオロジー特性が重なって観 測されることになる．水とスクワランから成る調製原料（ス クワラン濃度は $80 \mathrm{mass} \%$ ） $500 \mathrm{~g}$ に対して, 配合する界面活 性剂の量を変えて（1 g と $20 \mathrm{~g} ）$ 調製したモデル $\mathrm{O} / \mathrm{W}$ 乳化物 の $G^{*}$ の角周波数依存性を Fig. 6 に示す。界面活性剂を $20 \mathrm{~g}$ 配合したサンプルでは低角周波数域へ向かっての損失正接 $\tan \delta$ 值の増加に加え, $0.3 \mathrm{~s}^{-1}$ 付近に極大を示す緩和モードも 見られる。一方, 界面活性剂を $1 \mathrm{~g}$ と極端に減らしたサンプ ルでは，この緩和モードは全くなく（ $\tan \delta$ 曲線の極小值が $10^{-3}$ オーダーまで低下), 低角周波数側へ向かっての $\tan \delta$ 值 の増加が見られるのみである。界面活性剤は水中で会合体を 形成するが，水との界面で活性剂分子が平面状に並ぶものが 乳化には適することより, 活性剤を $20 \mathrm{~g}$ 配合したサンプル

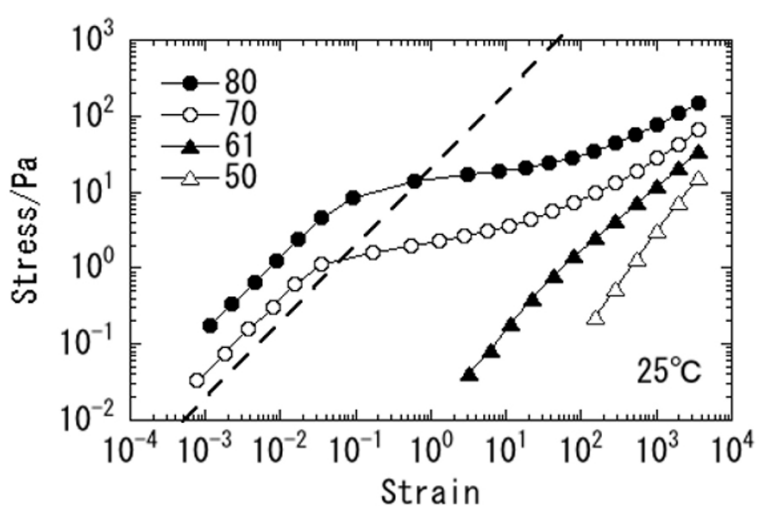

Fig. 5 Stress vs. strain plots for emulsion samples.
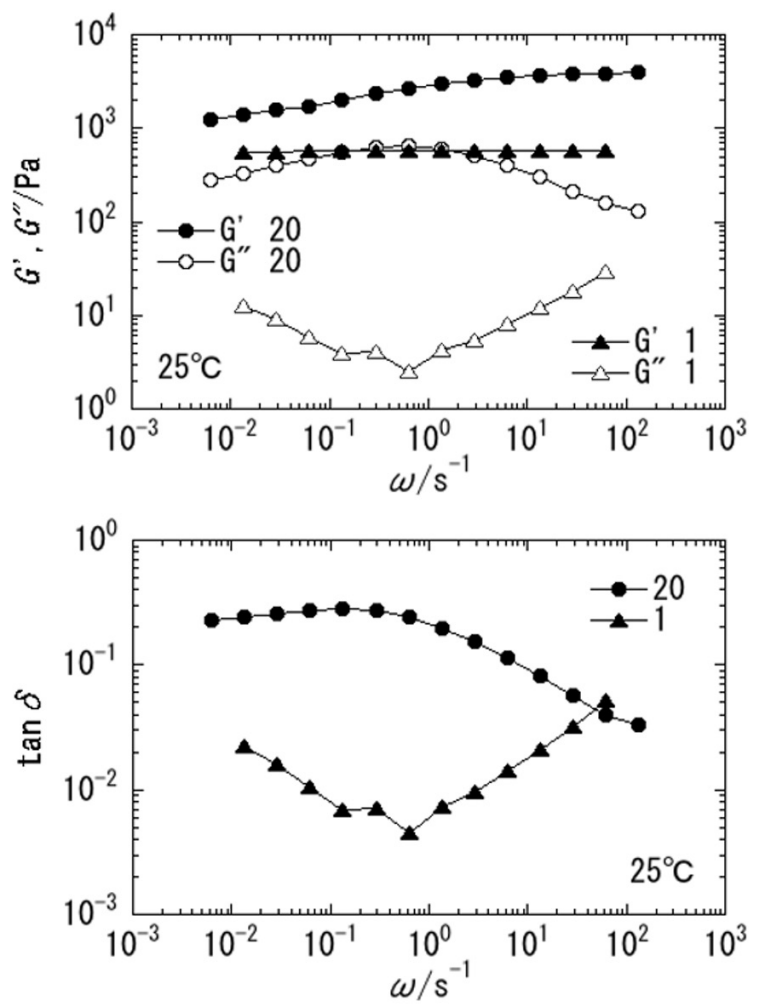

Fig. 6 Storage modulus $G^{\prime}$, loss modulus $G^{\prime \prime}$ (top panel) and loss tangent $\tan \delta$ (lower panel) vs. angular frequency plots for emulsion samples with different amount of surfactant. 
の $0.3 \mathrm{~s}^{-1}$ 付近に見られる緩和は連続相中に形成された層状 構造体の分子運動に起因するものと推定している。なお, Fig. 4 で示した乳化物についても, 界面活性剤量の使用量を 抑え，連続相中での会合体の形成を減らしたものである.

固体分散物のレオロジー特性の例を示さなかったが， $\eta$ の ずり速度依存性の高ずり速度域でずり硬化現象 ${ }^{7)}$ が見られる 点がある場合を除けば，おおむね，液滴分散物と類似の挙動 を示す。固体が配合された乳化分散型の化粧品では, 高ずり 速度域で若干のずり硬化現象がみられるものがある。レオロ ジー特性から化粧品の構造を推定する際, 分散質濃度が高い ものでは, Fig. 4 に見られる挙動の差に加え, Cox-Merz プ ロット ${ }^{5}$ を行うと溶液との区別がし易い. Fig. 7 に Fig. 4 の サンプルについての結果を示す。高分子溶液では複素粘性率 $|\eta *|$ 值と $\eta$ 值の一致が良いが, 乳化物では $|\eta *|>\eta$ となり, 両剤型の違いを区別し易い。分散物で $|\eta *|>\eta$ となるのは, 静置時に形成されていた凝集体の架橋構造（| $\mid$ *|值に反映） が定常流動下では壊れる（ $\eta$ 值に反映）ためと推察している

一般的に，分散質濃度が低い製剂では，溶液と分散物をレ オロジー的に区別するのは難しい。しかしながら，分散質濃 度が低い化粧品の場合, 感触制御と保存安定性の向上のため に，何らかの増粘剤が配合される。増粘剤として高分子が配 合されることが多いが，秋山ら ${ }^{8)}$ の報告のように，配合され た増粘剤が単なる高分子なのか, 微架橋ゲルなのか, 高分子 の幾何学的な絡み合いとは異なる物理架橋点が存在するのか 等を, レオロジー的に判断することが可能である. $\eta$ のずり 速度依存性が全ずり速度域でずり軟化であったり，CoxMerz プロットで $\eta<\mid \eta$ *|であれば微架橋ゲルが配合されてい ることがわかる。また, $\eta$ のずり速度依存性において down 過程の $\eta$ 值が up 過程の $\eta$ 值より小さい場合には, 静置時に
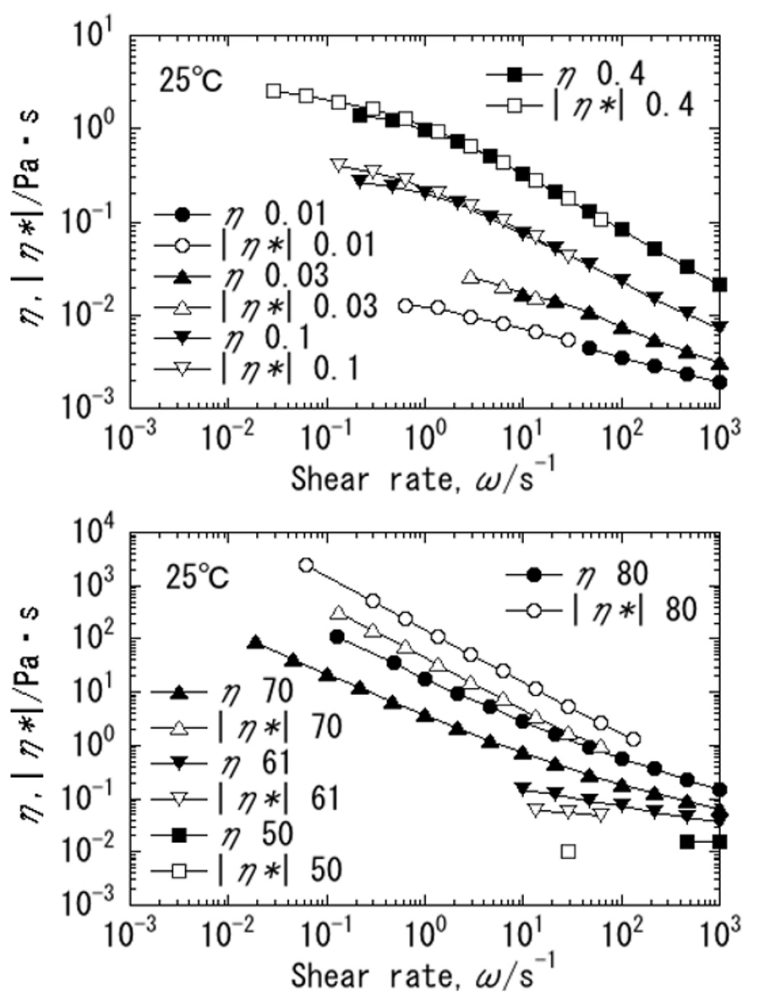

Fig. 7 Cox- Merz plots for polymer solution samples (upper panel) and emulsion samples (lower panel).
高分子の幾何学的な絡み合いとは異なる物理架橋点が形成さ れていることが示唆される。ささらには，乳化物の安定性の違 いをサンプルの降伏值の有無と関係づけて理解することもで きる。

化粧品では $\alpha$ ゲルの共存により系が増粘されている場合 がある．形成されている $\alpha$ ゲルが同心球状なのか，板状な のかをレオロジー的に区別することが可能である。 ステアリ ン酸ジメチルアミノプロピルアミドと直鎖ステアリルアル コールとから $\alpha$ ゲルが得られるが，使用する直鎖アルコー ルの一部を分岐アルコール（イソステアリルアルコール）に 置き換えると, 得られる $\alpha$ ゲルの構造を変えることができ る。イソステアリルアルコール比率（全アルコール配合量中 に占める分岐アルコール量の割合）が 0 の場合にはほぼ板状 の $\alpha$ ゲルサンプルが，0.4ではほぼ同心球状の $\alpha$ ゲルから成 るサンプルを調製できる（Fig. 8 の直交ニコル下での光学顕 微鏡像を参照)。Fig. 9 に両サンプルについて得た $G^{*}$ の角周 波数依存性を, Fig. 10 に $G^{*}$ の昇温過程での温度依存性を示 す. Fig. 9 の結果より, 同心球状の $\alpha$ ゲルに富むサンプルで は，低角周波数域へ向かっての $\tan \delta$ 值の増加が見られるの に対して，板状の $\alpha$ ゲルに富むサンプルでは低角周波数域 へ向かっての $\tan \delta$ 值の増加に加えて角周波数 $0.3 \mathrm{~s}^{-1}$ 付近に 別の緩和モードがみられる。低角周波数域へ向かっての $\tan \delta$ 值の増加は $\alpha$ ゲル粒子間の滑りに, $0.3 \mathrm{~s}^{-1}$ 付近の緩和は板状 の $\alpha$ ゲル内部の分子運動に関係する緩和と推定している9 . Fig. 10 の結果より $26^{\circ} \mathrm{C}$ 付近に転移点（ $\beta$ 相 $\rightarrow \alpha$ 相）に起因 するレオロジーパラメータの不連続点が, $36^{\circ} \mathrm{C}$ 付近に Fig. 9 の $0.3 \mathrm{~s}^{-1}$ に見られる緩和モードが見られる。 $\beta$ 相から $\alpha$ 相への転移点は $\alpha$ ゲルの形状の違いに関係なく観測される が, $G^{*}$ の温度依存性測定では板状に富む $\alpha$ ゲルサンプルで のみこの転移に起因する挙動が観測される。また， $G^{*} の$ 角 周波数依存性測定においても $0.3 \mathrm{~s}^{-1}$ 付近の緩和は板状 $\alpha$ ゲ ルに富むサンプルにおいてのみ観測される。これらの観測傾 向を活用すれば， $\alpha$ ゲルの形状が同心球状なのか板状なのか を判断できることになる

上記に記した結果は $\alpha$ ゲルのモデルサンプルについての 結果であるが，板状の $\alpha$ ゲルが共存する乳化物でも同様な 挙動が観測でき, 液滴に加えて板状の $\alpha$ ゲルも存在してい ることを知ることができる。また，Fig. 6 で示したように， 余㮃界面活性剂が形成する会合体の共存をレオロジー的に判 断できることも多い. $G^{*}$ の角周波数依存性や $G^{*}$ の温度依 存性測定を行うことにより相転移や緩和モードの有無を知る ことができ，これらの情報が構造推定を行う際に大いに役立 つ、ただし，界面活性剤が形成する会合体そのものについて の基礎的なレオロジーデータの蓄積は別途必要である.
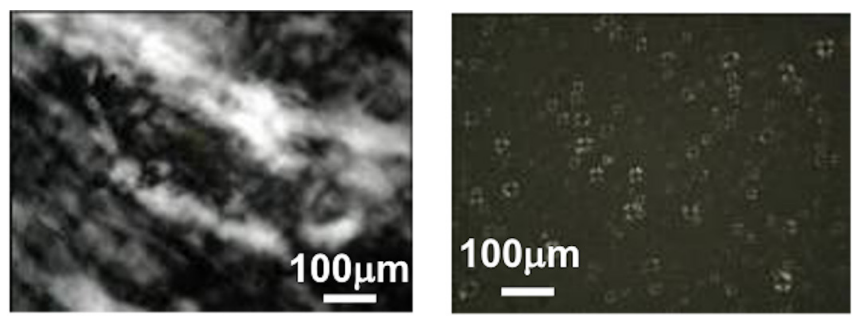

Fig. 8 Cross-polarized optical microscope for samples with different iso-stearylalcohol ratio of 0 (left panel) and 0.4 (right panel). 

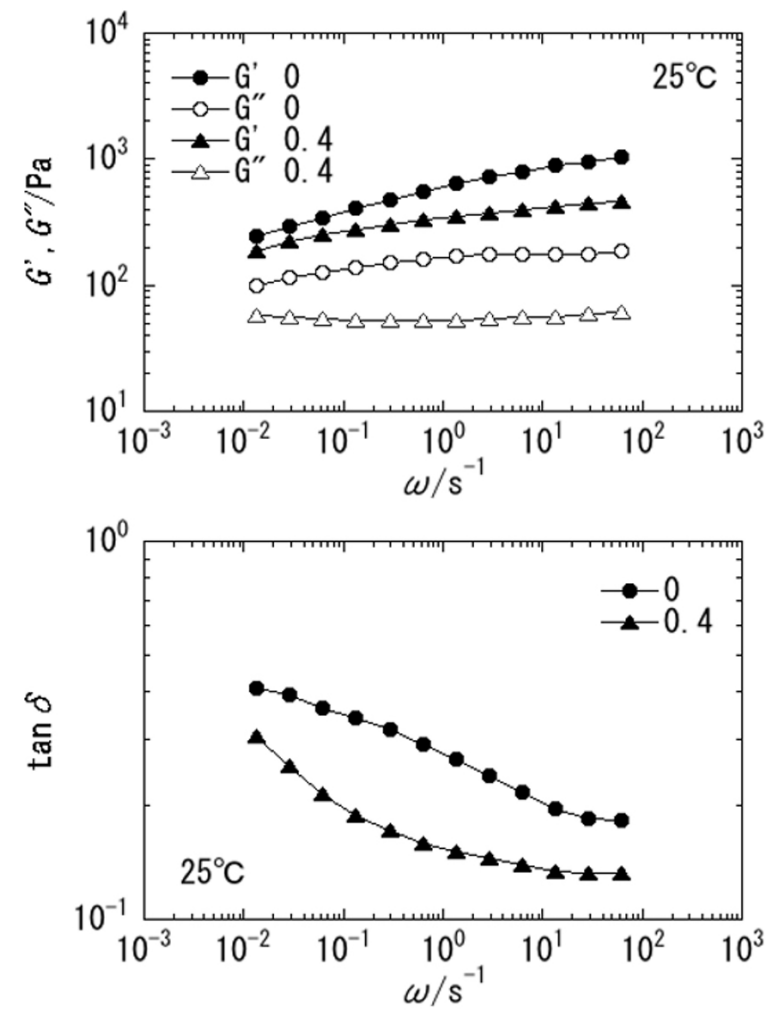

Fig. 9 Storage modulus $G^{\prime}$, loss modulus $G^{\prime \prime}$ (upper) and loss tangent $\tan \delta$ (lower) vs. angular frequency plots for samples with different iso-stearylalcohol ratio.

\section{3. おわりに}

レオロジーによる化粧品開発支援の一つとして化粧品感触 のレオメータを用いた計測（サイコレオロジー計測）を行っ た. 力学起源の感触であれば, 感触認知時の化粧製剤の状態 を測定セル中で再現し，認知時の動作を模した計測モードで のレオロジー測定やトライボロジー測定を行うことにより計 測できた。塗布後の化粧肌の感触については化粧製剤の計測 では無理で，化粧肌での計測を試みた。法線方向の位置と力 の制御も可能な, 応力制御式の回転型レオメータを用いて化 粧肌の計測を行った． 測定プローブを化粧肌へ当て易いこと より, 上腕内側部を測定対象に選び, 負荷の少ない上腕部の 固定法を工夫し, 計測時間を短くすることににより, 化粧肌 での計測もできそうな結果を得た。

化粧品のレオロジーを知るための一歩として, 乳化物のレ オロジー特性の把握を高分子溶液のそれと比較する形で行っ た。高分子溶液についても高分子糸まりが分散した系と見な し, 分散質および分散質接触部での運動性の違いから, 乳化 物のレオロジー特性を定性的に把握した。両系のレオロジー 特性に大きな差が生じるのは分散質接触部の運動性の違いに ある. 高分子溶液では接触部が高分子鎖の幾何学的な絡み合 いであるために，高分子鎖に沿った鎖のレプテーション運動 により絡み合い点（接触部）の解消が生じる。この状態は, 分散質が密に詰まった高濃度域でも変わらず，高分子溶液で は速度は遅くはなるが常にマクロに流動できる（低ずり速度 域で一定の $\eta$ 值を示す)。乳化物では分散質 (液滴) の接触 部が接触点で, 接触面内方向での滑りのみが許される運動と 考えられる。液滴が集まってできた凝集体が系全体に広がる
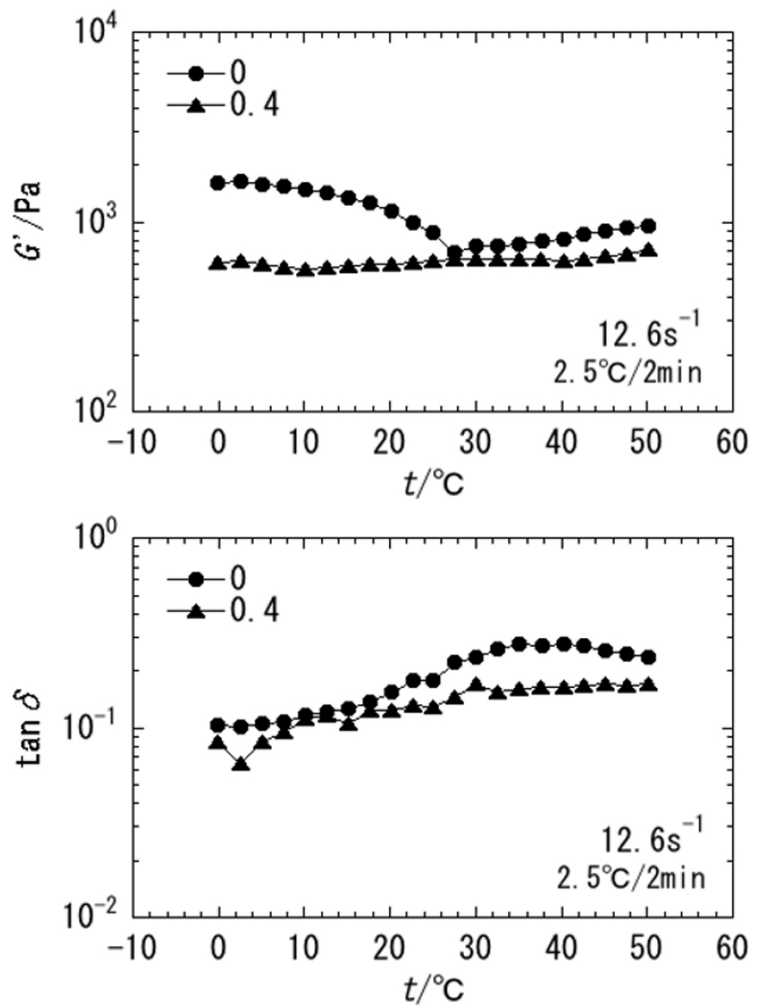

Fig. 10 Storage modulus $G^{\prime}$ (upper panel) and loss tangent $\tan \delta$ (lower panel) vs. temperature plots for samples with different iso-stearylalcohol ratio.

ようになると動ける空間がなくなり，周りの凝集体との協同 的な動きが必要になり, 滑り運動の速度の低下と滑り距離の 減少が生じてくる。液滴の充填が十分進んだ状態になると, 乳化物はマクロには流動できなくなる（固体状態になる）. マクロに流動させるには液滴の協働運動を生じさせるに必要 な応力（降伏応力）以上の応力を印加する必要がある.

化粧品開発へのレオロジーの応用可能性は大きく, 基礎 データを蓄積しつつ, 若い方々が新たな応用を試みられるこ とを期待しております。

\section{謝 辞}

この度は, 功績賞という栄誉ある賞をいただき, 身に余る 光栄と感謝しております。選考にご尽力いただきました関係 各位に感謝申し上げます。サイコレオロジー研究会について は，私一人では無理で，立ち上げの勧めと自由な進め方をお 許しいただきました上田隆宣会長（故人），運営にご協力い ただきましたコアメンバーの方々，ならびに会場をご提供い ただきました皆様のご支援の賜物です。最後に，共同研究者 としてお付き合いいただいた花王株式会社の研究員の皆様に 心より感謝致します。

\section{REFERENCES}

1) Nabata Y, Suzuki K, Yoshida K, Namiki N, Shibata M, Nihon Reoroji Gakkaishi (J Soc Rheol Jpn), 35, 79 (2007).

2) Nabata Y, Hyomen, 46, 37 (2008).

3) Nabata Y, “Keshouhin no Reoroji”, pp. 66-102 (2015), 
Yoneda Publishing, Tokyo (in Japanese).

4) Nabata Y, FRAGRANCE JOURNAL, 46, 34 (2018).

5) Osaki K, "Reoroji no Sekai”, pp. 81-97 (2012), Morikita Publishing, Tokyo (in Japanese).

6) Takahashi Y, Kurashina N, Noda I, Doi M, J Rheol, 38, 699 (1994).
7) Larson RG, "The Structure and Rheology of Complex Fluids", Chap. 6 (1999), Oxford University Press.

8) Akiyama E, Nabata Y, Yago Y, Nihon Reoroji Gakkaishi ( $J$ Soc Rheol Jpn), 49, 261 (2021).

9) Osaki K, “Reoroji no Sekai”, p. 135 (2012), Morikita Publishing, Tokyo (in Japanese). 